\title{
ANALISIS DAN DESAIN WEBSITE CULTURE-VID BERBASIS VIDEO SHARE DALAM RANGKA MELESTARIKAN BUDAYA BANGSA DAN KEARIFAN LOKAL NUSANTARA
}

\author{
Feby Atwodini Muqtadiroh, Amna Shifia Nisafani, Rifqi Rizany \\ Jurusan Sistem Informasi, Fakultas Teknologi Informasi, Institut Teknologi Sepuluh Nopember \\ Kampus ITS Sukolilo, Surabaya, 60111 \\ Telp: (031) 5999944, Fax: (031) 5964965 \\ E-mail: feby@is.its.ac.id
}

\begin{abstract}
Indonesia has a very diverse cultures. Nevertheles, there are many difficulties in disseminating knowledge about those cultures. One of the reasons is due to the lack of dissemination channels. Here, we are proposing a channel namely Culture-vid, which adopts the advantages of video share website to facilitate users to access any cultural information aiming to spread the knowledge and to preserve the Indonesian culture. This research focuses on analysing and designing video share-based website using prototype method, which comprises of three stages. Those stages are benchmarking phase, analysis and design phase, and validation phase. The result of this reasearch are Software Requirement Specification document and Design document that will serve as a basis for developing Culture-vid, so that it can be implemented to preserve the Indonesian culture.
\end{abstract}

\section{Abstrak}

Kebudayaan yang dimiliki oleh bangsa Indonesia merupakan kebudayaan yang majemuk dan sangat kaya ragamnya. Namun, sejumlah orang yang memiliki pengetahuan mengenai budaya asli di Indonesia memiliki banyak keterbatasan dalam menyebarkan pengetahuannya. Keterbatasan tersebut salah satunya disebabkan oleh minimnya dukungan media dalam menyebarkan informasi budaya. Oleh karena itu, penelitian ini bertujuan untuk mengembangkan sebuah sistem yang mengadopsi kelebihan dari website video share untuk memudahkan pengguna mengakses informasi terkait budaya yang bertujuan untuk menyebarluaskan pemahaman dan melestarikan budaya Indonesia. Sistem tersebut adalah Culture-vid. Riset kali ini berfokus pada proses analisis dan desain dari sistem yang akan dikembangkan dengan menggunakan metode Protoptyping. Pada Prototyping, terdapat 3 tahapan pengerjaan yang dimulai dengan tahapan benchmarking untuk penggalian kebutuhan, analisis dan desain sistem, serta validasi hasil analisis dan desain. Hasil dari riset analisis dan desain Culture-vid ini berupa sebuah dokumen spesifikasi kebutuhan sistem dan desain Culture-vid yang disesuaikan dengan kebutuhan dan tujuan pelestarian budaya. Dokumen analisis dan desain tersebut nantinya akan digunakan untuk pengembangan dari perangkat lunak Culture-vid, sehingga dapat diimplementasikan untuk melestarikan budaya bangsa Indonesia.

Kata kunci: kebutuhan sistem, analisis, desain, website, video share, kearifan lokal.

\section{PENDAHULUAN}

Indonesia adalah bangsa yang memiliki keanekaragaman dan keunikan budaya dan kesenian. Kebudayaan yang dimiliki oleh bangsa Indonesia merupakan kebudayaan yang majemuk dan sangat kaya ragamnya. Sejumlah orang yang memiliki pengetahuan mengenai budaya asli di Indonesia memiliki banyak keterbatasan dalam menyebarkan pengetahuannya. Salah satu keterbatasan tersebut adalah media persebarannya yang membuat pengetahuan dan sumber pengetahuan mengenai budaya asli Indonesia menjadi suatu hal yang langka dan terbatas, sehingga penyebaran pengetahuan mengenai budaya menjadi ikut terbatas. Selama ini masyarakat melindungi pengetahuan tradisional hanya semampunya, melestarikannya kadang hanya sekadarnya, atau bahkan untuk penyambung hidup kurang bisa diandalkan. Misalnya, masyarakat transmigran Jawa di Lampung sanggup melestarikan budaya Jawa di Lampung (Purwaningsih, 2012). Hal ini juga dikarenakan pemerintah yang kurang aktif untuk menghimbau masyarakat akan pentingnya mejaga/melestarikan budaya bangsa. Selain itu, regulasi yang mengatur tentang perlindungan kekayaan budaya pun tidak jelas bagaimana kebijakan-kebijakannya (DPD, 2012). Di Indone- 
sia, pemerintah telah menunjuk Dinas Kebudayaan dan Pariwisata (Disbudpar) secara resmi untuk menangangi permasalahan pelestarian budaya Indonesia. Tetapi saat ini peran dari Disbudpar untuk melestarikan budaya bangsa dirasa kurang maksimal, sehingga diperlukan juga kesadaran yang tinggi dari masyarakat Indonesia untuk lebih mengenal kebudayaan yang ada di setiap daerah di Indonesia.

Salah satu solusi alternatif yang dapat dilakukan untuk membantu melestarikan budaya bangsa adalah dengan menggunakan sebuah teknologi informasi. Konsep ini digagas sejak tahun 2012 oleh (Muklason dkk, 2012) melalui Knowledge Management System (KMS). KMS yang dibangun berupa sebuah VirtualNusantara yang dikembangkan sebagai suatu integrasi sistem yang bertujuan untuk melestarikan budaya dan kearifan lokal Indonesia. Bahkan konsep VirtualNusantara dipertajam dan diulas dalam (Nisafani dkk., 2012) tentang pengembangan Wisdom Management System (WMS) untuk konservasi warisan berkelanjutan. Kedua paper tersebut membahas usulan sebuah framework untuk konservasi budaya Indonesia. Lebih lanjut, konsep framework tersebut telah dikembangkan suatu sistem yang bernama WikiBudaya (Nisafani dkk, 2014; Muqtadiroh dkk., 2014) Fokus riset WikiBudaya adalah pada pengembangan sistem pelestarian budaya berbasis artikel. Sebenarnya, di Indonesia sendiri sudah ada beberapa situs website yang membahas tentang budaya. Beberapan contohnya adalah wikipedia.com dan budaya-Indonesia.org. Tetapi untuk saat ini, kedua situs tersebut memiliki beberapa kelemahan yang dirasa cukup fatal (Nisafani dkk., 2014). Untuk situs wikipedia.com, kelemahan yang pertama adalah situs tersebut tidak secara spesifik memberikan informasi tentang kebudayaan. Yang kedua, tidak ada kejelasan terkait dengan orang yang bertanggung jawab terhadap informasi yang diberikan (reviewer), dan ditambah dengan sumber yang dicantumkan kebanyakan berasal dari halaman blog yang kebenarannya tidak dapat dipertanggung jawabkan. Begitu juga pada situs budaya-Indonesia.org. Situs ini secara spesifik telah memberikan informasi tentang kebudayaan Indonesia, namum memiliki kelemahan yang berupa tidak adanya sumbersumber yang ada pada artikel yang dimuat pada situs budaya-Indonesia.org, serta tidak adanya pihak atau orang yang bertanggung jawab terhadap pengelolaan dari situs budayaIndonesia.org. Ketiadaan sumber yang valid dan akurat serta dapat dipercaya menyebabkan tejadinya distorsi informasi yang akan berujung pada kepunahan budaya karena diragukan keabsahannya.
Penjelasan di atas memberikan gambaran lemahnya media penyebaran informasi yang akurat tentang budaya. Keterbatasan seperti media penyebaran merupakan tantangan tersendiri dalam menyebarkan pengetahuan yang dimiliki. Oleh karena itu perlu adanya teknologi yang lebih menarik dalam rangka penyebaran pengetahuan mengenai budaya yang tidak hanya melalui artikel budaya, namun juga diperlukan media untuk mempertukarkan informasi budaya dengan banyak orang yang lebih interaktif melalui situs web berbasis video share. Visualisasi pada video memudahkan seseorang untuk menyerap sebuah informasi yang ada dibandingkan dengan media penyebaran lainnya seperti buku bergambar, tulisan, dan audio. Penggunaan alat bantu visual telah lama dikenal untuk meningkatkan, memperkuat dan menjelaskan ide atau konsep tertentu untuk memungkinkan seseorang lebih memahami apa yang dijelaskan.

Dengan demikian, penelitian ini bertujuan untuk mengembangkan sebuah sistem pertukaran informasi budaya dengan format video dan berbasis web. Sistem tersebut diberi nama CultureVid. Adapun rumusan masalah yang ingin diselesaikan adalah apa saja kebutuhan fungsional dan non fungsional dari CultureVid, serta bagaimana bentuk desain dari Culture-Vid sehingga mampu membantu melestarikan budaya bangsa. Adapun metode yang digunakan adalah metode prototipe. Metode ini dipilih karena mampu mengefisiensikan pembuatan desain suatu perangkat lunak, bahkan mampu memberikan saran perbaikan untuk desain selanjutnya secara iteratif (Erikkson dkk., 2000).

\section{METODOLOGI}

Metode yang digunakan dalam penelitian ini adalah Model Prototipe yang berfokus pada iterasi analisis dan desain sistem. Adapun tahapan yang dilalui dalam penelitian ini dapat dilihat pada Gambar.

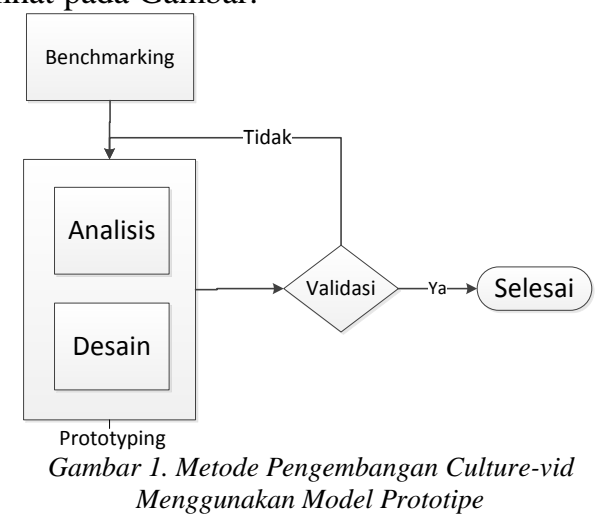
Menggunakan Model Prototipe 


\section{Benchmarking}

Tahap ini merupakan tahap awal pada tahap desain perangkat lunak. Tahap ini menuntut adanya penggalian kebutuhan dari situs yang sudah ada, di antaranya adalah anlisis proses bisnis, analisis kebutuhan pengguna, dan analisis kebutuhan sistem dari sistem-sistem yang sudah ada sebelumnya.

\section{Analisis Kebutuhan Stakeholder}

Tahap ini merupakan tahap awal pada tahap perancangan perangkat lunak. Pada tahap ini terdapat beberapa sub tahapan yang menuntut adanya komunikasi dengan stakeholder, di antaranya adalah anlisis proses bisnis, analisis kebutuhan pengguna, dan analisis kebutuhan sistem.

- Analisis Proses Bisnis

Melakukan analisis terhadap proses bisnis yang diinginkan pada instansi stakeholder. Hal ini bertujuan untuk memahami konsep proses bisnis dari aplikasi video budaya.

- Analisis Kebutuhan Pengguna

Alalisis kebutuhan pengguna merupakan aktivitas yang dilakukan untuk mengetahui apa saja yang dibutuhkan oleh pengguna pada perangkat lunak yang akan dibuat. Hasil dari identifikasi kebutuhan pengguna ini akan direpresentasikan ke dalam fitur perangkat lunak yang akan dibuat serta usecase. Pada tahap ini akan menghasilkan dokumen Target Audience \&Customer Benefit, User Needs \& Stories, dan Interview Notes.

- Analisis Kebutuhan Sistem

Hasil dari identifikasi kebutuhan sistem akan digunakan untuk membuat desain sistem, maka komponen - komponen yang harus ada pada aktivitas ini adalah meliputi usecase, spesifikasi fitur, dan kebutuhan fungsional dan non fungsional. Luaran dari tahapan adalah menghasilkan beberapa dokumen yaitu Requirements Specifications, Use-cases, Feature Specs, dan Design Documents.

\section{Desain Sistem}

Desain sistem yang dilakukan pada tahapan ini adalah desain struktural dan desain perilaku sistem. Desain struktural sistem merupakan desain database dengan menggunakan ERD (Entity Relational Diagram), dan melakukan generate ERD ke dalam bentuk CDM (Conceptual Diagram Model), dan PDM (Physical Diagram Model). Hal ini dilakukan untuk mempermudah generate ke dalam bahasa SQL (Structured Query Language). Sedangkan pada desain perilaku digunakan UML (Unified Modelling Language). Tahap desain ini adalah tahapan untuk membuat use-case diagram, Sequence Diagram, Activity Diagram, dan class diagram menggunakan UML.
- Class diagram

Pada tahap ini akan digambarkan bagaimana hubungan antar objek dan method-method apa saja yang terdapat pada setiap class. Definisi - definisi class yang diilustrasikan pada class diagram akan diimplementasikan pada tahap construction.

- Use-case diagram

Use-case diagram berisi gambaran mengenai interaksi antara sekelompok proses dengan sekelompok aktor, menggambarkan fungsionalitas dari sebuah sistem yang dibangun dan bagaimana sistem berinteraksi dengan dunia luar. Use-case diagram dapat digunakan selama proses analisis untuk menangkap kebutuhan sistem dan untuk memahami bagaimana sistem seharusnya bekerja.

- Activity Diagram Activity Diagram menggambarkan berbagai alir aktivitas dalam sistem yang sedang dirancang, bagaimana masing - masing alir berawal, decision yang mungkin terjadi, dan bagaimana mereka berakhir. Activity Diagram juga dapat menggambarkan proses paralel yang mungkin terjadi pada beberapa eksekusi.

- Sequence Diagram

Sequence Diagram menggambarkan interaksi antar objek di dalam dan di sekitar sistem (termasuk pengguna, display, dan sebagainya) berupa pesan yang disusun dalam suatu urutan waktu. Diagram ini menjelaskan kelas - kelas dan objek yang terlibat untuk menjalankan fungsionalitas dari skenario yang ada. Secara khusus, diagram ini berasosiasi dengan use-case .

- Desain Antarmuka

Pada tahapan ini dilakuakan rancangan user interface secara deskriptif. Hal ini bertujuan untuk memudahkan dalam hal pengimplementasian hasil desain perangkat lunak.

\section{HASIL DAN PEMBAHASAN}

Bagian ini membahas tentang hasil dari proses analisis dan perancangan Culture-Vid.

\subsection{Proses Bisnis}

Menurut paper (Nisafani dkk., 2014), pelestarian budaya Indonesia untuk wilayah Jawa Timur saat ini menjadi tanggung jawab pihakDinas Kebudayaan dan Pariwisata Jawa Timur (Disbudpar Jatim). Pengelolaan budaya pada hakekatnya juga menjadi tanggung jawab bersama. Untuk itulah diharapkan melalui Culture-vid, peran seluruh masyarakat luas dapat dioptimalkan. Hal ini mengingat bahwa Jawa Timur memiliki wilayah yang luas yang mana 
Muqtadiroh, dkk., Analisis dan Desain Website Culture-Vid Berbasis Video Share dalam Rangka..

berimplikasi menyebarnya informasi budaya di wilayah-wilayah tersebut. Culture-vid adalah salah satu usulan sistem yang dikembangkan berbasis website yang secara khusus menampung dan membagi informasi terkait kebudayaan- kebudayaan yang ada di Indonesia dalam bentuk video. Culture-vid diharapkan nantinya secara resmi dikelola oleh Dinas Kebudayaan dan Pariwisata Jawa Timur (Disbudpar Jatim).

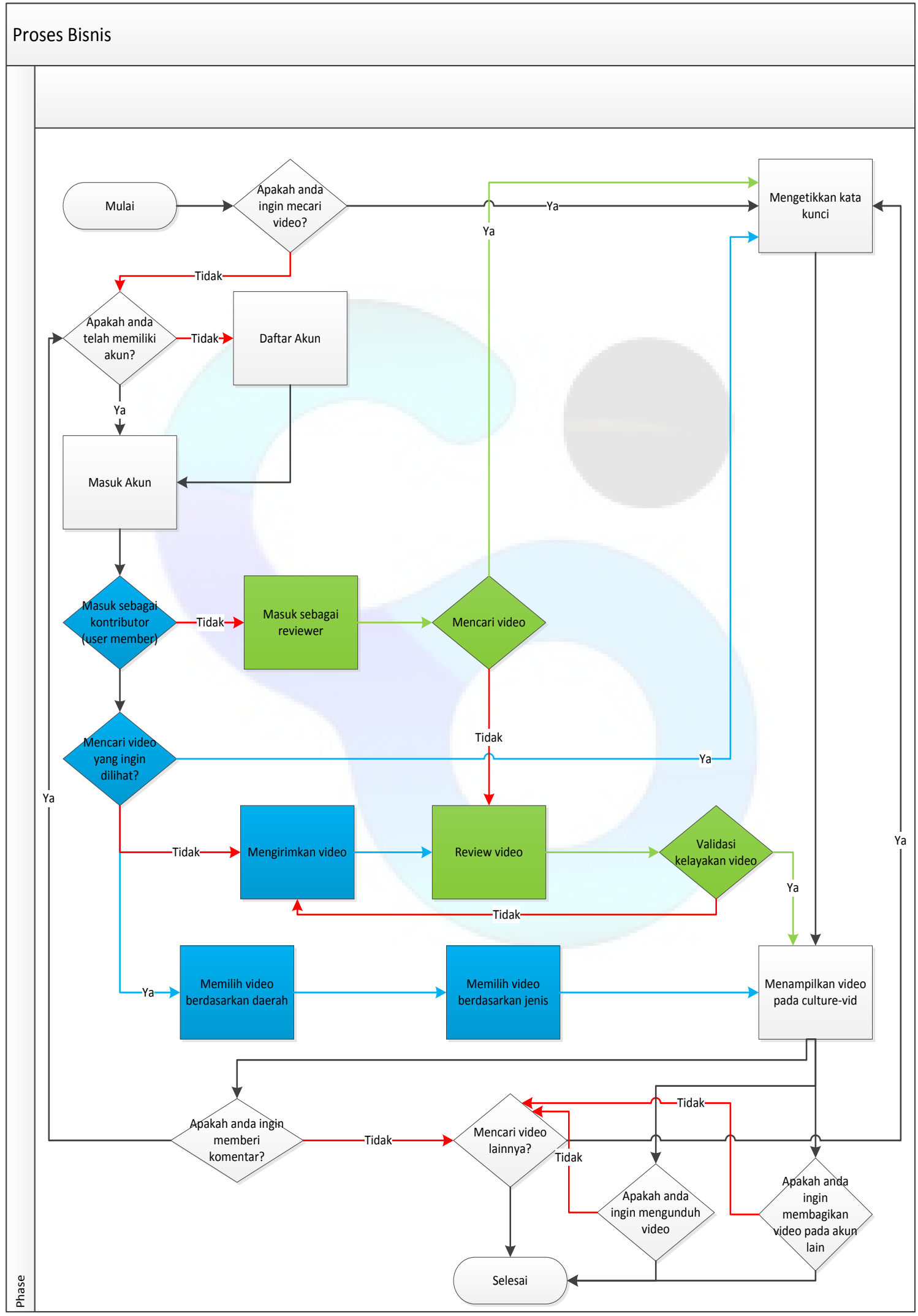

Gambar 2. Proses Bisnis Culture-vid dalam Rangka Pelestarian Budaya 
Berikut adalah gambaran proses bisnis dari sistem Culture-vid untuk Pelestarian Budaya Indonesia berdasarkan hasil wawancara dengan pihak Disbudpar Jatim dan penurunan dari penelitian (Nisafani dkk., 2014; Muqtadiroh dkk.; 2014). Gambar 2 menunjukkan aktivitas apa saja yang dapat diakomodasi oleh Culturevid dalam rangka melestarikan budaya bangsa. Ada beberapa peran dalam Cukture-vid diantara adalah: Pengguna Umum, Kontributor, dan Reviewer. Pengguna Umum dapat melihat video budaya yang dikehendaki dan dapat memberitahukan kepada orang lain melalui fungsi share. Sedangkan Kontributor dapat berkontribusi dalam menyampaikan video budaya agar dapat dinikmati oleh pengunjung. Namun sebelum video dari Kontributor dapat dinikmati pengunjung, video tersebut harus melalui proses review terlebih dahulu oleh Reviewer yang melibatkan pakar budaya atau pihak yang bertanggung jawab dalam pelestarian budaya Indonesia.

\subsection{Benchmarking}

Benchmarking dilakukan terhadap beberapa situs video share seperti Youtube.com, Kissanime.com, dan Vimeo.com. Keunggulan dari sistem yang terdapat dalam beberapa layanan situs tersebut digunakan sebagai acuan dalam melakukan pendefinisian kebutuhan minimum dari sistem Culture-vid guna memberikan kemudahan pengguna nantinya. Berikut adalah rangkuman hasil benchmarking.

Tabel 1.Hasil Benchmark terhadap Website berbasis Video share

\begin{tabular}{|c|c|c|c|c|c|}
\hline & $\begin{array}{l}\text { Yout } \\
\text { ube }\end{array}$ & $\begin{array}{c}\text { Kissani } \\
\text { me }\end{array}$ & Vimeo & User & $\begin{array}{l}\text { KF/ } \\
\text { KNF }\end{array}$ \\
\hline $\begin{array}{l}\text { Pengguna } \\
\text { dapat } \\
\text { melakukan } \\
\text { login }\end{array}$ & $\sqrt{ }$ & $\sqrt{ }$ & $\sqrt{ }$ & $\begin{array}{c}\text { Mem } \\
\text { ber }\end{array}$ & $\mathrm{KF}$ \\
\hline $\begin{array}{l}\text { Pengguna } \\
\text { dapat } \\
\text { mengunduh } \\
\text { video }\end{array}$ & - & $\sqrt{ }$ & - & $\begin{array}{c}\text { Mem } \\
\text { ber }\end{array}$ & $\mathrm{KF}$ \\
\hline $\begin{array}{l}\text { Pengguna } \\
\text { dapat } \\
\text { mengungga } \\
\mathrm{h} \text { video }\end{array}$ & $\sqrt{ }$ & $\sqrt{ }$ & $\sqrt{ }$ & $\begin{array}{c}\text { Mem } \\
\text { ber }\end{array}$ & $\mathrm{KF}$ \\
\hline $\begin{array}{l}\text { Sistem } \\
\text { diperuntukk } \\
\text { an konten } \\
\text { tertentu }\end{array}$ & ALL & $\begin{array}{l}\text { video } \\
\text { anime }\end{array}$ & ALL & $\begin{array}{l}\text { Non } \\
\text { Mem } \\
\text { ber }\end{array}$ & KNF \\
\hline $\begin{array}{l}\text { Validasi } \\
\text { Video, } \\
\text { Sumber } \\
\text { video jelas }\end{array}$ & - & $\sqrt{ }$ & - & & $\mathrm{KNF}$ \\
\hline $\begin{array}{l}\text { Pengguna } \\
\text { dapat } \\
\text { memberika } \\
\text { n komentar }\end{array}$ & $\sqrt{ }$ & $\sqrt{ }$ & $\sqrt{ }$ & $\begin{array}{c}\text { Mem } \\
\text { ber }\end{array}$ & $\mathrm{KF}$ \\
\hline $\begin{array}{l}\text { Pengguna } \\
\text { dapat }\end{array}$ & $\sqrt{ }$ & $\sqrt{ }$ & $\sqrt{ }$ & ALL & $\mathrm{KF}$ \\
\hline
\end{tabular}

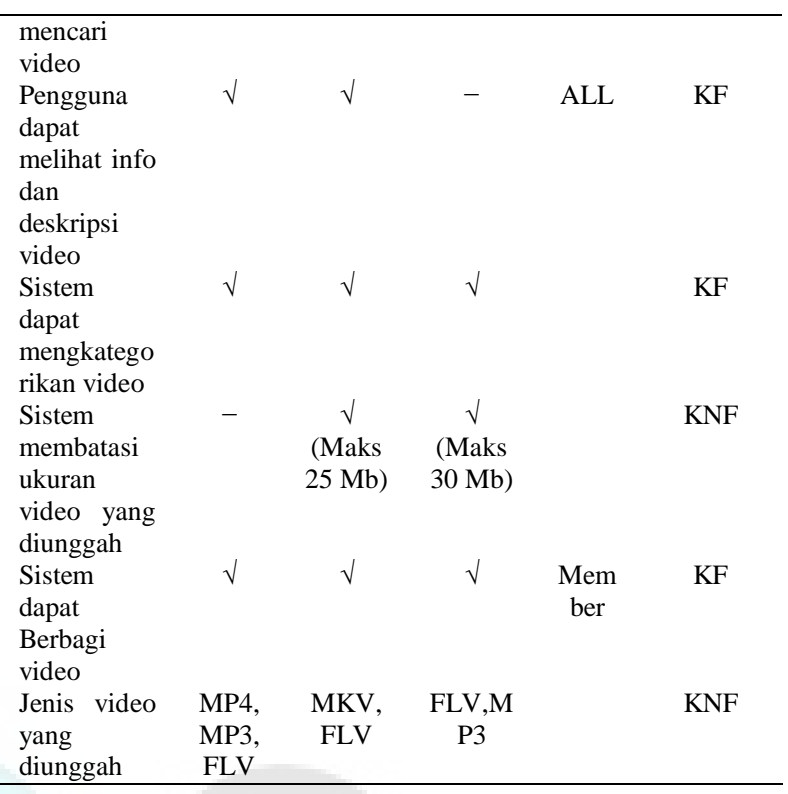

\subsection{Perancangan Prototipe}

Pada perputaran prototipe yang pertama telah dihasilkan spesifikasi kebutuhan pengguna yang tertulis dalam kebutuhan fungsional dan kebutuhan non-fungsional. Prototipe pertama tersebut dibuat berdasarkan hasil penelitian sebelumnya (Nisafani dkk., 2014) yang mendefinisikan kebutuhan umum dari pihak Disbudpar Jatim yang diselaraskan dengan hasil benchamark atas minimum requirement dari website berbasis video share. Adapun hasil prototipe pertama fokus kepada tiga fungsi, yaitu Cari Video, Unduh Video, dan Beri Komentar.

Pada putaran prototipe yang kedua, penulis mencoba menggambarkan prototipe secara visual dari umpan balik yang diterima pada saat iterasi prototipe yang pertama. Proses penggambaran prototipe aplikasi dilakukan dengan menggunakan GUI (Graphical User Interface.) Tampilan GUI dapat menjadi cara yang efektif untuk merepresentasikan perangkat lunak yang akan dibuat dalam bentuk visual. Hasil keluaran dari proses perputaran prototipe yang kedua merupakan penyempurnaan fungsi dari prototipe pertama dan fokus kepada pengembangan empat fungsi lain, yaitu Daftar, Unggah Video (oleh Kontributor), Profilku, dan List Video (oleh Reviewer). Untuk prototipe ketiga, desain antar muka yang dihasilkan fokus kepada fungsi Daftar Master Akun, Daftar Master Video, dan Pesan Konfirmasi.

Terkahir, prototipe keempat muncul karena adanya masukan dari pihak Disbudpar Jatim untuk menampilkan deskripsi video budaya yang diunggah oleh Kontributor dan telah direview oleh Reviewer, sehingga pengunjung tidak hanya dapat melihat video saja namun juga deskripsi video budaya tersebut. Selain penambahan fungsi 
Muqtadiroh, dkk., Analisis dan Desain Website Culture-Vid Berbasis Video Share dalam Rangka..

deskripsi video, terdapat tambahan fungsi baru yaitu fungsi untuk berbagi yang bertujuan untuk memudahkan penyebarluasan video kebudayaan tersebut. Untuk setiap prototipe yang dihasilkan harus melalui proses verifikasi terlebih dahulu dengan pihak stakeholder.

\subsection{Kebutuhan Fungsional dan Kebutuhan non Fungsional}

a) Kebutuhan Fungsional

Pada tahap berikut ini akan dilakukan pengelompokan kebutuhan yang berdasasarkan fungsional pada unit yang berhubungan dengan perangkat lunak yang akan dibuat. Berikut ini merupakan kebutuhan fungsional utama yang dibutuhkan pengguna :

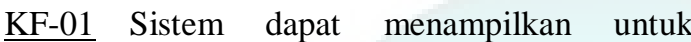
melakukan daftar (register) akun, masuk (login) akun, dan keluar (logout) akun

KF-02 Sistem dapat mengunggah video

$\underline{\mathrm{KF}-03}$ Sistem dapat mengunduh video

$\underline{\mathrm{KF}-04}$ Sistem dapat update video

$\underline{\text { KF-05 }}$ Sistem dapat melakukan pencarian video

KF-06 Sistem mempunyai deskripsi informasi tentang video apa yang disampaikan kepada pengguna

$\underline{\text { KF-07 }}$ Sistem dapat menampilkan komentar

KF-08 Sistem dapat menampilkan kategori video

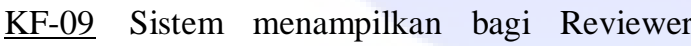
untuk melakukan review dan validasi video

KF-10 Sistem Sistem menampilkan untuk memberikan dan hapus komentar

KF-11 Sistem dapat menampilkan histori dari video yang pernah dilihat oleh Kontributor dan direview

$\underline{\text { KF-12 }}$ Sistem dapat menampilkan bagi pengguna (aktor) selain Admin untuk mengelola akun pribadi

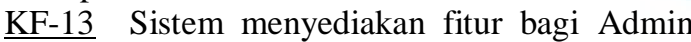
(reviewer \& sistem) untuk mengelola master, termasuk didalamnya adalah data master akun, video, dan komentar

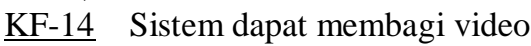

b) Kebutuhan non Fungsional

Pada tahap ini akan dilakukan inisialisasi terhadap semua kebutuhan non-fungsional perangkat lunak sesuai dengan umpan balik yang diberikan calon pengguna.

- Usability Requirement Usability adalah kebutuhan non fungsional terkait dengan kemudahan penggunaan sistem atau perangkat lunak oleh Pengguna.

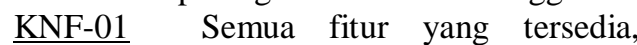
dapat digunakan sebagaimana fungsinya
KNF-02 Tidak adanya menu atau tombol yang membingungkan (ambiguitas) bagi pengguna

- Reliability and security requirement

Reliability yaitu kebutuhan yang terkait dengan kehandalan sistem atau perangkat lunak. Yang termasuk dalam reliabilitas sistem adalah faktor keamanan (security) sistem.

$\underline{\text { KNF-03 }}$ Sistem dapat menampilkan seluruh konten dari Culture-vid

KNF-04 Hanya admin yang dapat mengakses master database Culture-vid

KNF-05 Hanya admin sistem yang dapat menghapus video, akun,dan komentar yang dianggap tidak layak

- Portability Requirement

Portability adalah kemudahan dalam pengaksesan sistem khususnya terkait dengan faktor waktu dan lokasi pengaksesan, serta perangkat atau teknologi yang digunakan untuk mengakses. Perangkat atau teknologi tersebut meliputi perangkat lunak, perangkat keras, dan perangkat jaringan.

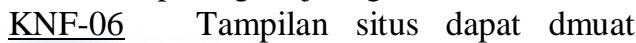
dan menyesuaikan ukuran device

- $\quad$ Supportability Requirement

Supportability adalah kebutuhan terkait dengan dukungan dalam penggunaan sistem atau perangkat lunak.

KNF-07 Sistem dapat diakses pada segala OS (Operating System)

\subsection{Use case}

Pada tahap ini akan dilakukan pembuatan use case berdasarkan fungsi-fungsi yang ada pada perangkat lunak yang akan dikembangkan. Berikut adalah use case Culture-vid:

Tabel 2. Daftar Use Case untuk Sistem Culture-vid

\begin{tabular}{cl}
$\begin{array}{c}\text { Kode use- } \\
\text { case }\end{array}$ & \multicolumn{1}{c}{ use-case } \\
\hline UC-01.01 & Daftar akun \\
UC-01.02 & Masuk akun \\
UC-01.03 & Keluar akun \\
UC-01.04 & Lihat detail akun pribadi \\
UC-01.05 & Ubah detail akun pribadi \\
UC-01.06 & Lihat data Pengguna \\
UC-01.07 & Hapus Akun \\
UC-01.08 & Cari Pengguna \\
UC-01.09 & Validasi contributor \\
UC-01.10 & Validasi Reviewer \\
UC-01.11 & Ubah kata kunci
\end{tabular}




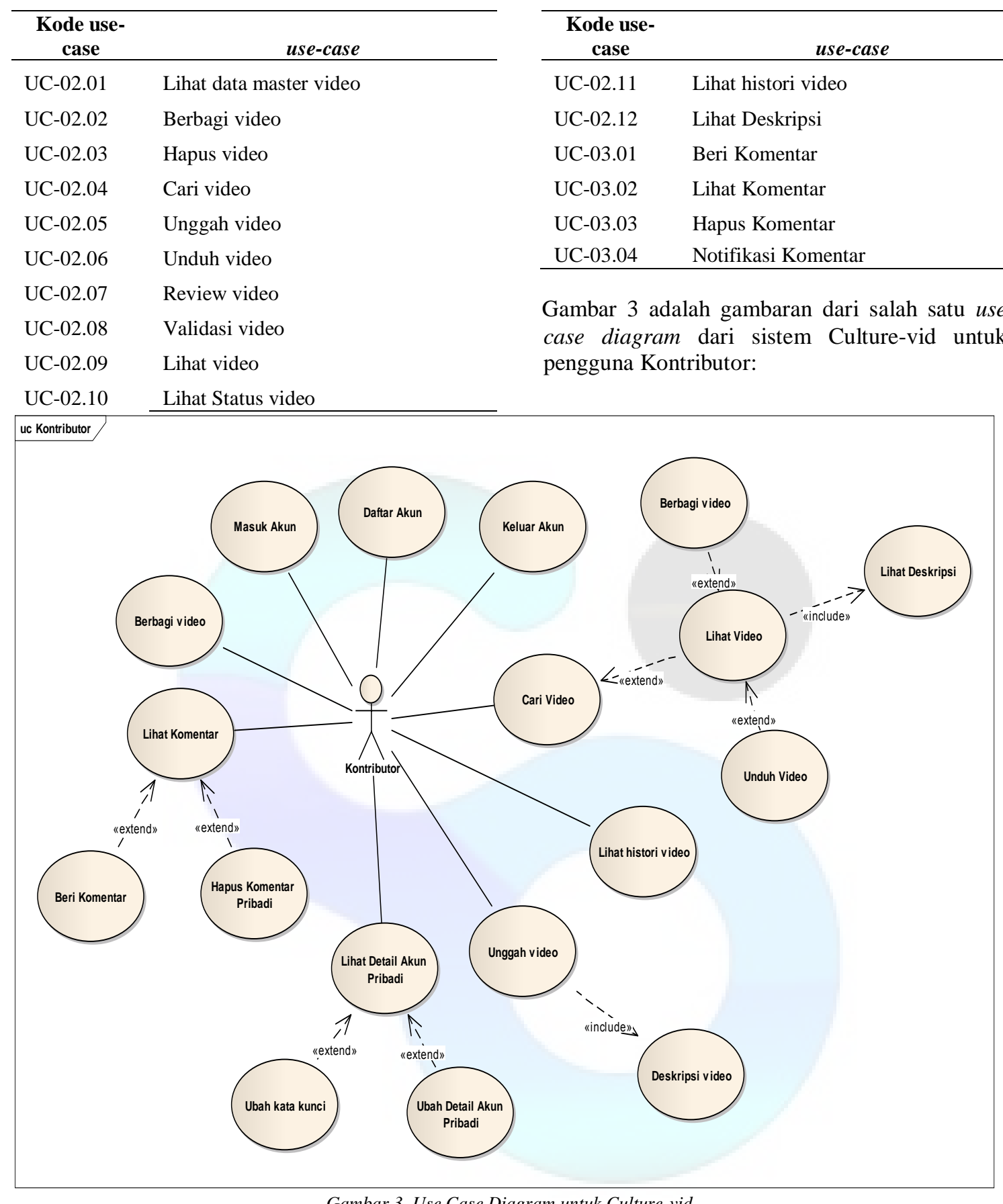

Gambar 3. Use Case Diagram untuk Culture-vid

\subsection{Class Diagram}

Gambar 4 menunjukkan class diagram dari Culture-vid yang diturunkan dari daftar use case. Dari use case tersebut, dihasilkan 3 object utama yang dibentuk menjadi kelas-kelas yakni kelas Akun, Video, dan Komentar. Untuk role dari masing-masing akun diturunkan dari kelas Akun yang terdiri dari 3 kelas turunan yakni: Control Akun, kelas Kontributor, dan kelas Reviewer.

\subsection{Activity Diagram}

Gambar 5 adalah salah satu contoh diagram aktivitas Culture-vid untuk use case Lihat Video untuk semua jenis pengguna (UC-02.09)

Gambar 6 menampilkan diagram aktivitas Unggah Video oleh Kontributor dalam sistem Culture-vid (UC-02.05) 
Muqtadiroh, dkk., Analisis dan Desain Website Culture-Vid Berbasis Video Share dalam Rangka..

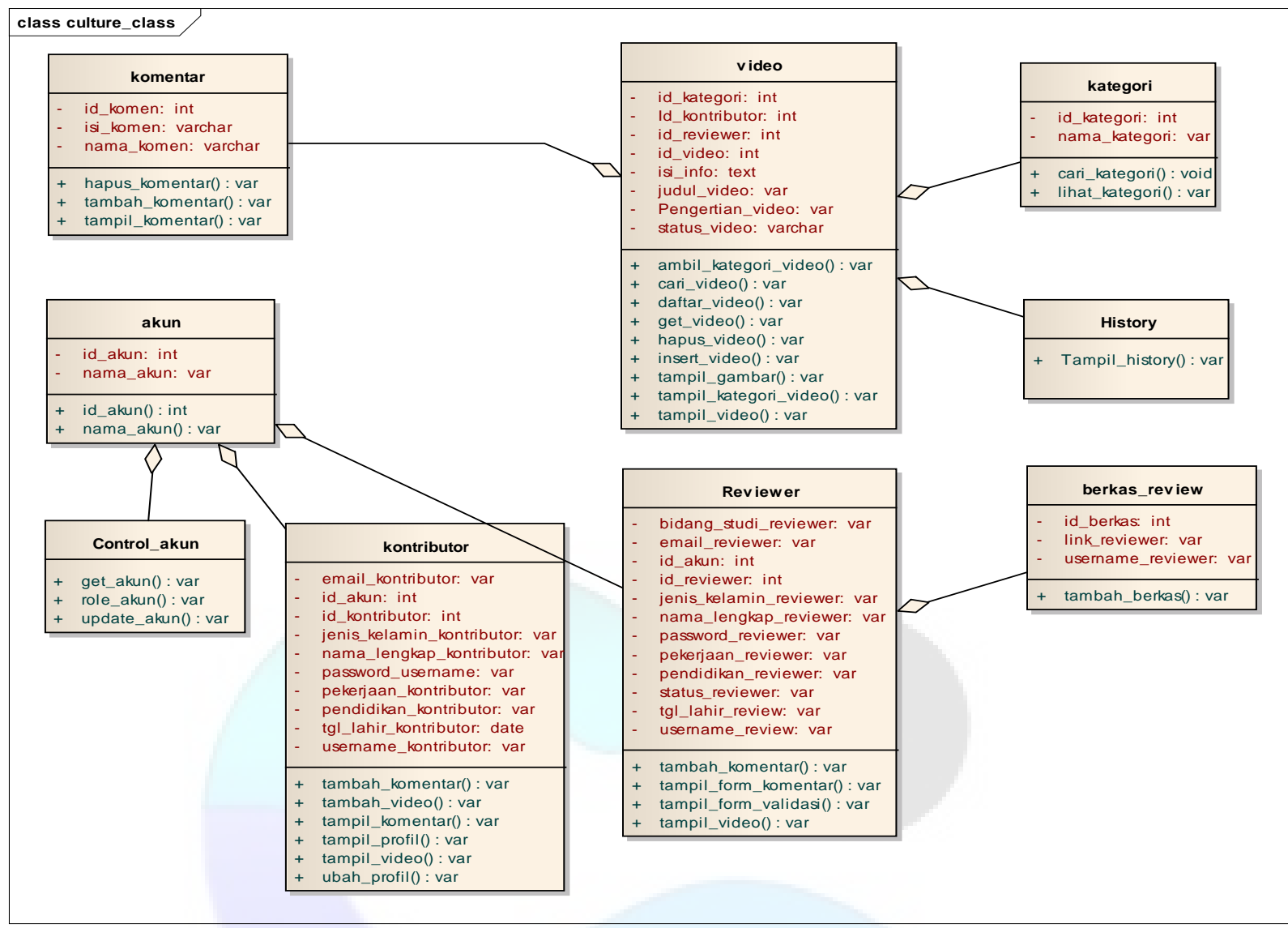

Gambar 4. Class Diagram untuk Culture-vid

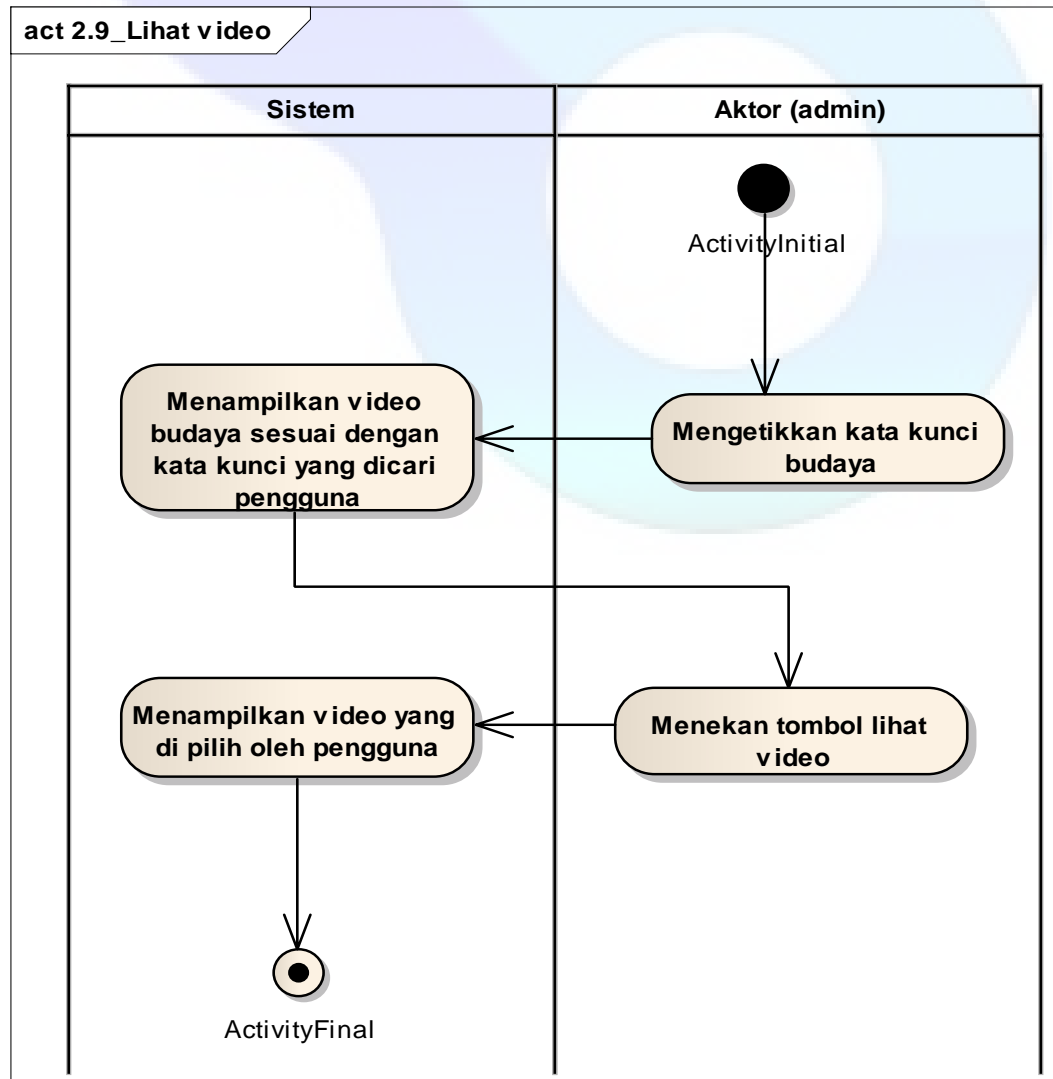

Gambar 5. Activity Diagram pada Culture-vid untuk Aktivitas Lihat Video 


\subsection{Sequence Diagram}

Berikut adalah salah satu contoh Sequence Diagram Culture-vid untuk use case Lihat Video (UC-02.09) sebagaimana diagram aktivitas pada Gambar 5.
Berikut adalah gambar Sequence Diagram untuk aktivitas Unggah Video sebagaimana penjelasan Activity Diagram pada Gambar 6.

\subsection{ERD}

Adapun desain dari database yang digunakan untuk pengembangan Culture-vid ditunjukkan gambar 9.
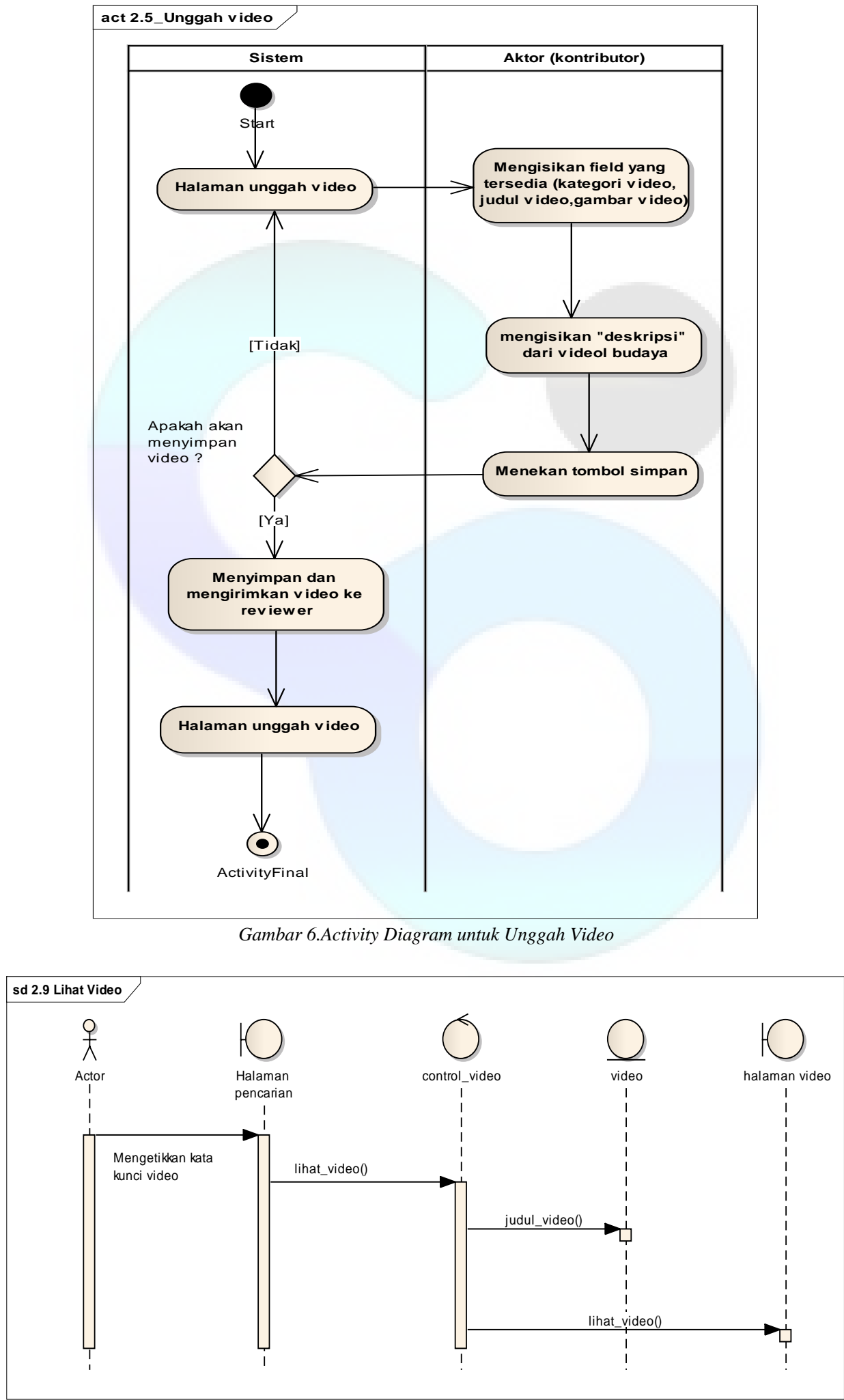

Gambar 7. Sequence Diagram pada Culture-vid untuk Aktivitas Lihat Video 


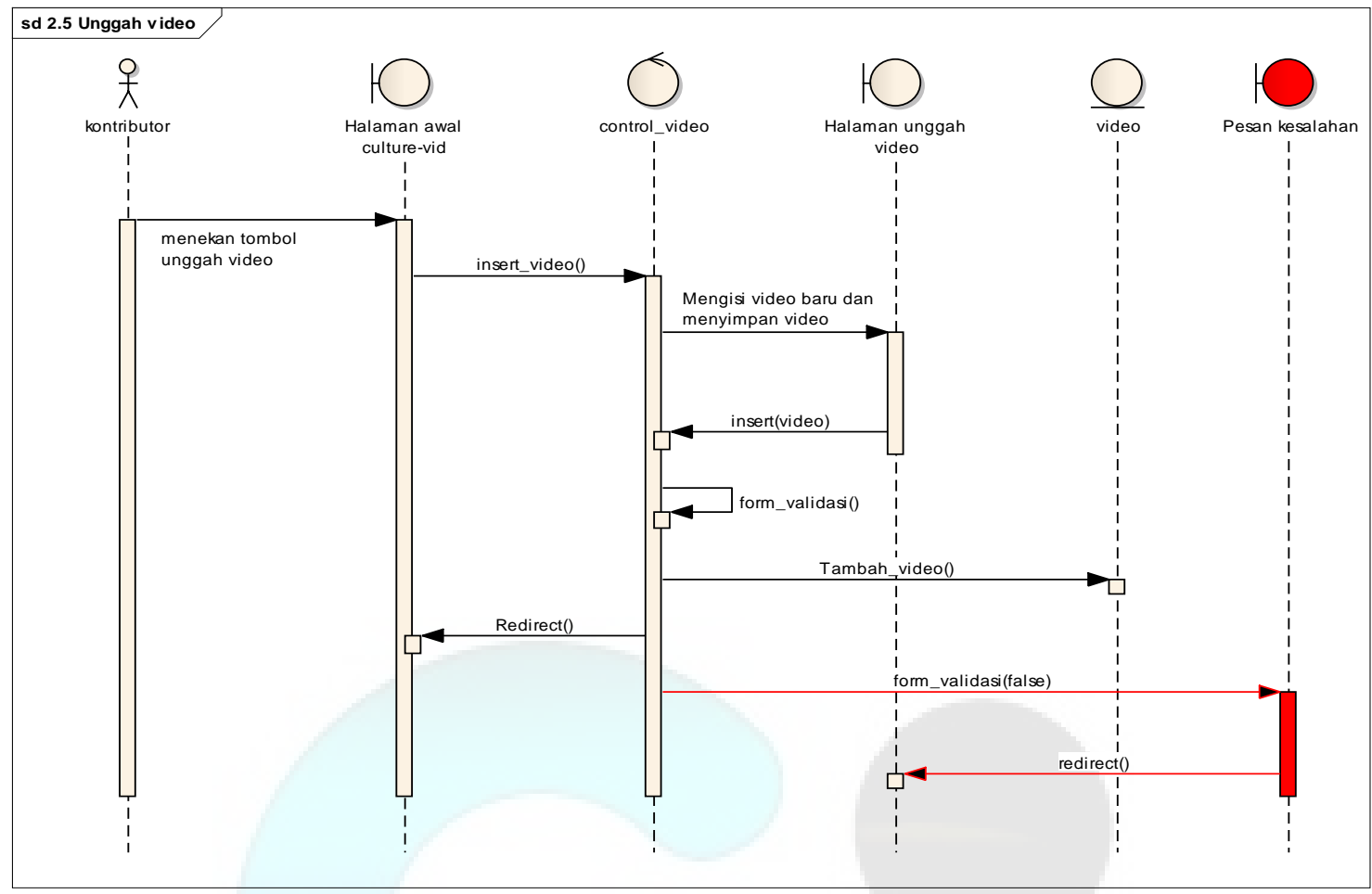

Gambar 8. Sequence Diagram pada Culture-vid untuk Aktivitas Unggah Video

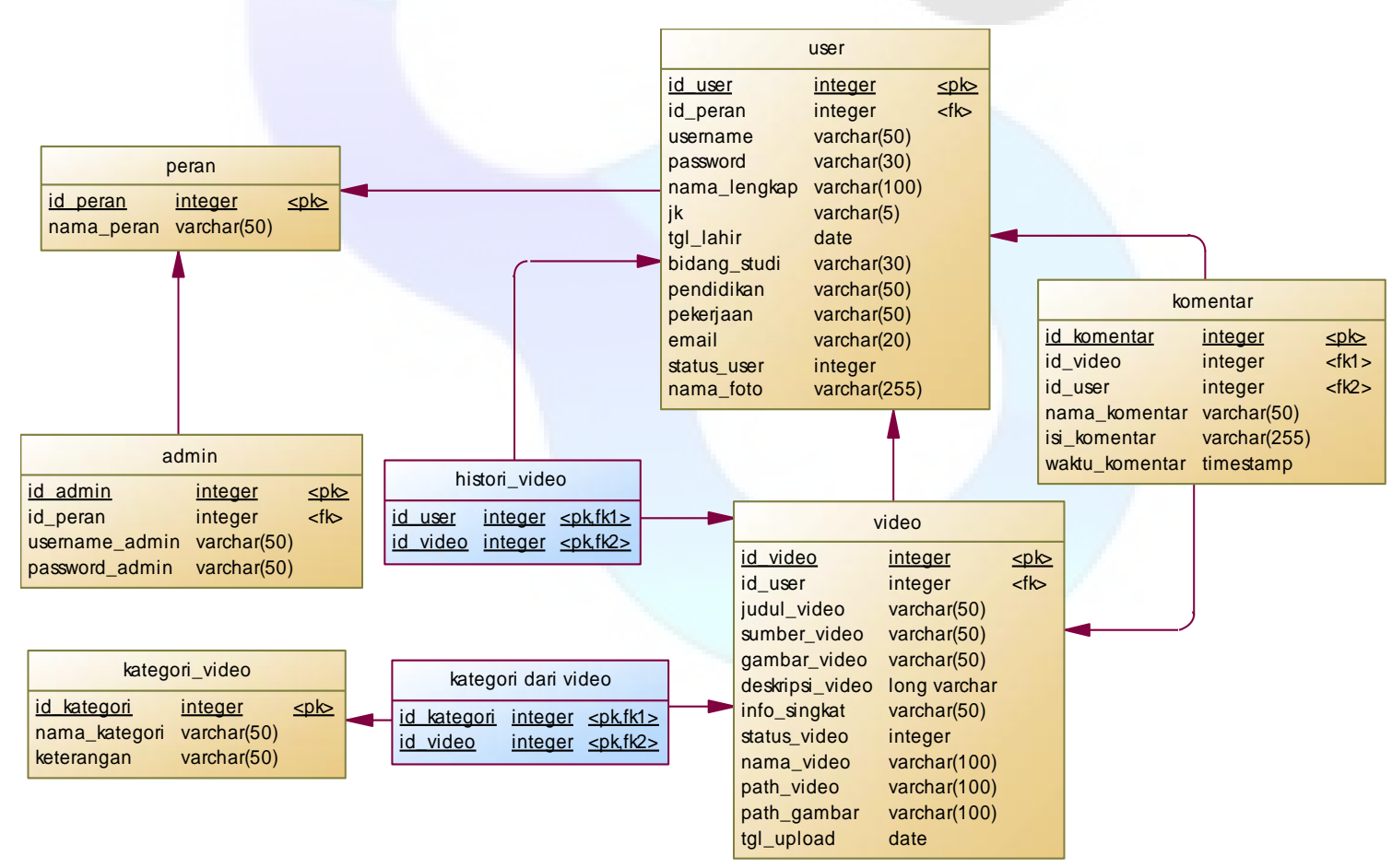

Gambar 9. ERD pada Culture-vid

\subsection{Desain Antarmuka}

Dari hasil analisis dan desain pada subbab sebelumnya, maka dapat digambarkan rancangan dari antarmuka pengguna Culture-vid. Antarmuka ini menggambarkan bagaimana interaksi antara sistem dengan pengguna sesuai dengan pendefinisian use case. Berikut adalah contoh dari user interface yang telah dibuat.

\subsection{Validasi Kebutuhan dan Desain Menggunakan Requirement \&Design Traceability Matrix}

Berdasarkan pada desain yang telah dibentuk, disusun Requirement \& Design Traceability Matrixuntuk mengetahui bahwa semua desain telah memenuhi kebutuhan. Berikut ini adalah Requirement \& Design Traceability Matrix yang telah dibuat. 
Tabel 3.Rangkuman Desain Antarmuka Culture-Vid Berdasarkan Hasil Iterasi Prototipe

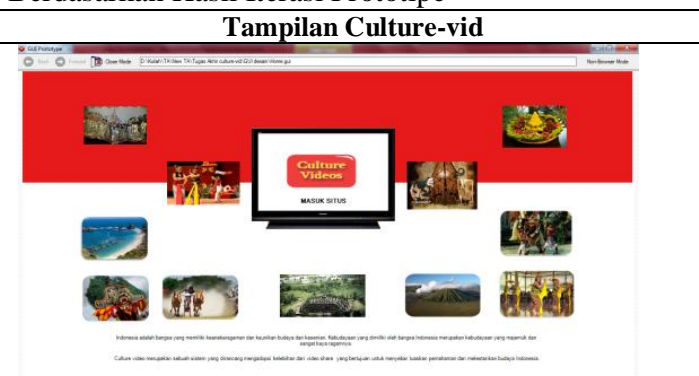

Merupakan tampilan awal dari situs bagi pengguna

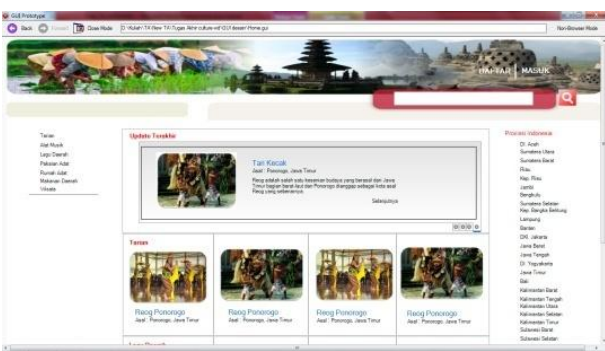

Pada halaman utama situs Culture-vid terdapat beberapa fungsi yaitu, fungsi "Cari video", "Cari berdasarkan daerah", "Cari berdasarkan jenis video", "Daftar", dan "Masuk".

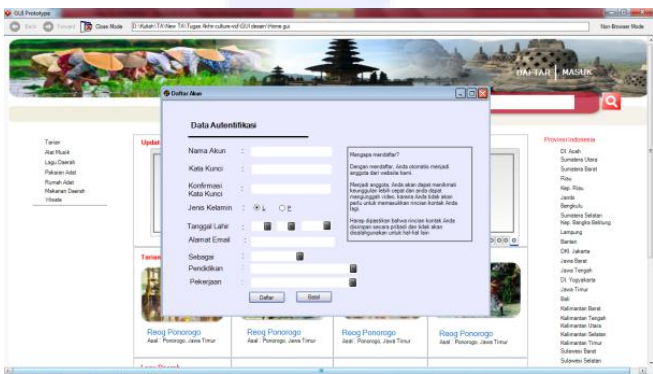

Untuk fungsi "Daftar" terdapat tombol BAFTAR |MASUK yang terletak di pojok kanan atas. Tombol tersebut digunakan untuk memindahkan pengguna dari halaman utama ke halaman Form pendaftaran. Langkah yang pertama adalah form untuk data autentifikasi.

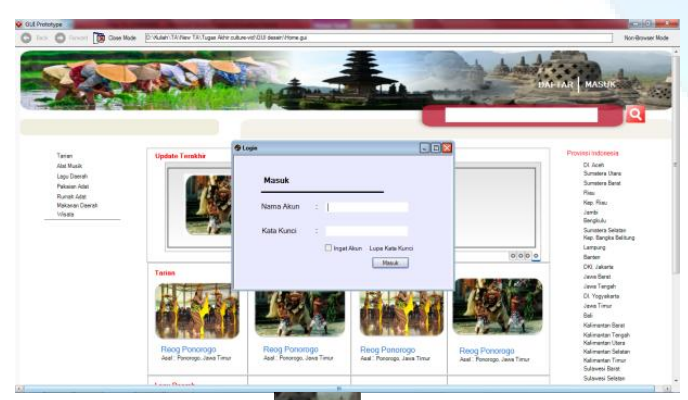

Pada tombol masuk mastika terdapat pilihan masuk berdasarkan hak akses dan akun yang dimiliki yaitu, kontributor dan reviewer. Ke 2 submenu tersebut akan mengarahkan pengguna ke halaman login masing-masing hak akses.

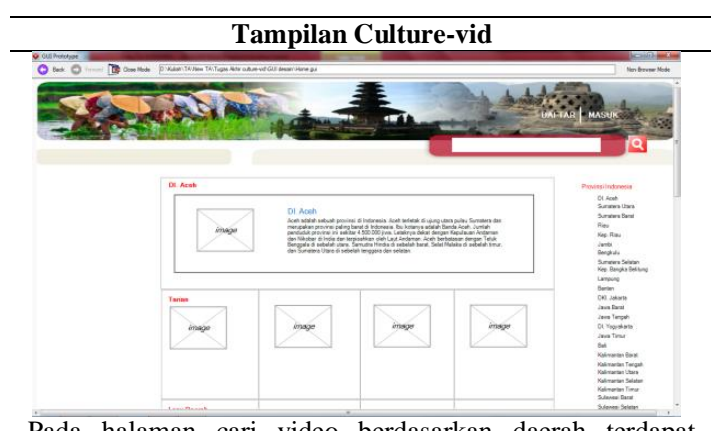

Pada halaman cari video berdasarkan daerah terdapat penjelasan mengenai daerah tersebut dan beberapa fungsi yaitu, fungsi "video berdasarkan jenis", "cari berdasarkan daerah".

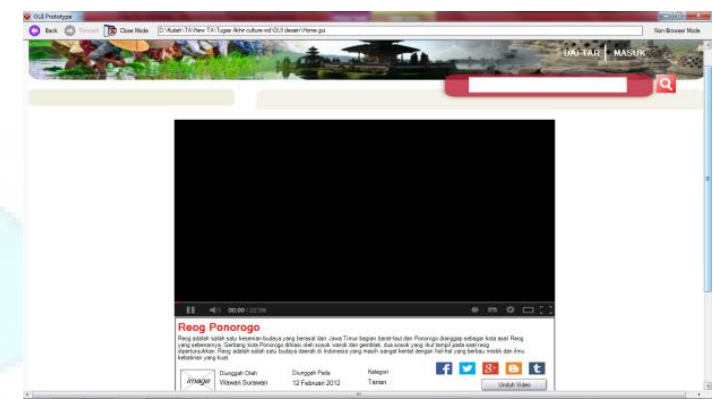

Pada halaman video berdasarkan daerah terdapat penjelasan mengenai video tersebut dan beberapa fungsi yaitu, fungsi "unduh video", "Beri komentar","Berbagi video".

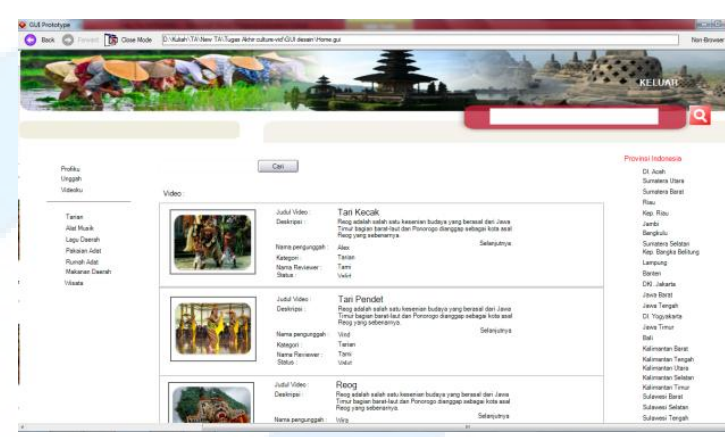

Pada halaman videoku,terdapat list video yang sudah kita unggah dan sudah divalidasi. Video tersebut sudah dapat dilihat di situs Culture-vid. 
Muqtadiroh, dkk., Analisis dan Desain Website Culture-Vid Berbasis Video Share dalam Rangka..

Tabel 4.Requirement \& Design Traceability Matrix dari sistem Culture-vid

\begin{tabular}{|c|c|c|c|c|c|}
\hline $\mathbf{K F}$ & Use-case & $\begin{array}{l}\text { Kode Use- } \\
\text { case }\end{array}$ & $\begin{array}{c}\text { Activity } \\
\text { Diagram }\end{array}$ & $\begin{array}{l}\text { Sequence } \\
\text { Diagram }\end{array}$ & Interface \\
\hline KF-01 & Daftar akun & UC-01.01 & AD.1 & SD.1 & I.1 \\
\hline KF-01 & Masuk akun & UC-01.02 & AD.2 & SD.2 & I. 2 \\
\hline KF-01 & Keluar akun & UC-01.03 & AD. 3 & SD. 3 & I. 3 \\
\hline KF-12 & Lihat detail akun pribadi & UC-01.04 & AD. 4 & SD.4 & I.4 \\
\hline KF-12 & Ubah detail akun pribadi & UC-01.05 & AD.5 & SD.5 & I. 5 \\
\hline KF-13 & Lihat data pengguna & UC-01.06 & AD.6 & SD.6 & I.6 \\
\hline $\mathrm{KF}-13$ & Hapus Akun & UC-01.07 & AD.7 & SD.7 & I.7 \\
\hline KF-13 & Cari pengguna & UC-01.08 & AD. 8 & SD. 8 & I.8 \\
\hline KF-13 & Validasi kontributor & UC-01.09 & AD.9 & SD.9 & I.9 \\
\hline KF-13 & Validasi reviewer & UC-01.10 & AD. 10 & SD.10 & I.10 \\
\hline KF-01 & Daftar akun reviewer & UC-01.11 & AD.11 & SD.11 & I.11 \\
\hline KF-12 & Ubah kata kunci & UC.01.12 & AD. 12 & SD.12 & I.12 \\
\hline KF-13 & Lihat data master video & UC-02.01 & AD. 13 & SD.13 & I.13 \\
\hline KF-14 & Berbagi video & UC-02.02 & AD. 14 & SD.14 & I.14 \\
\hline KF-13 & Hapus Video & UC-02.03 & AD. 15 & SD.15 & I. 15 \\
\hline KF-05 & Cari video & UC-02.04 & AD.16 & SD.16 & I.16 \\
\hline KF-02 & Unggah Video & UC-02.05 & AD. 17 & SD.17 & I. 17 \\
\hline KF-03 & Unduh video & UC-02.06 & AD. 18 & SD.18 & I. 18 \\
\hline KF-09 & Review & UC-02.07 & AD.19 & SD.19 & I. 19 \\
\hline KF-09 & Validasi & UC-02.08 & AD.20 & SD.20 & I. 20 \\
\hline KF-03 & Lihat Video & UC-02.09 & AD.21 & SD.21 & I. 21 \\
\hline KF-10 & Lihat status video & UC-02.10 & AD.22 & SD.22 & I. 22 \\
\hline KF-05 & Lihat Histori video & UC-02.11 & AD.23 & SD.23 & I. 23 \\
\hline KF-06 & Deskripsi video & UC-02.12 & AD.24 & SD.24 & I. 24 \\
\hline KF-06 & Lihat deskripsi & UC-02.13 & AD. 25 & SD.25 & I. 25 \\
\hline KF-10 & Beri Komentar & UC-03.01 & AD.26 & SD.26 & I. 26 \\
\hline KF-07 & Lihat Komentar & UC-03.02 & AD.27 & SD.27 & I. 27 \\
\hline KF-10 & Hapus Komentar & UC-03.03 & AD.28 & SD.28 & I. 28 \\
\hline
\end{tabular}

Dari Tabel 4 didapatkan bahwa semua desain telah sesuai dengan kebutuhan sistem.

\section{SIMPULAN DAN SARAN}

Keberhasilan pengembangan suatu sistem yang bertujuan untuk melestarikan budaya bangsa berbasis video share terletak pada kedalaman dan kebenaran hasil analisis dan desain. Dimana analisis dan desain Culture-vid dikembangkan melalui proses benchmarking dan pembuatan prototipe secara iteratif untuk hasil yang maksimal dan memenuhi kebutuhan stakeholder. Dibutuhkan empat kali iterasi prototipe untuk memenuhi empat belas kebutuhan fungsional sebagaimana didefinisikan pada subbab 3.3 dan subbab 3.4. Proses validasi atas requiremenet dan design dilakukan dengan membuat matrik kerunutan yakni melalui Requirement \& Design Traceability Matrix. Hasil validasi menunjukkan bahwa semua kebutuhan yang diperoleh dari wawancara, benchmarking, serta pembuatan prototipe telah sesuai. Untuk pengembangan selanjutnya, perlu adanya proses pengujian untuk kebutuhan non fungsional. Mengingat sistem Cuture-vid berbasis video share, tentu keamanan menjadi faktor utama yang perlu diperhatikan demi keberhasilan dan kualitas sistem yang dibangun.

\section{DAFTAR PUSTAKA}

Muklason, A., Muqtadiroh, F.A., Nisafani, A.S., Nurkasanah, I., 2012. VirtualNUSANTARA: A Knowledge Management System Framework for Cultural Heritage And Local Wisdom Conservation In Indonesia. In International Conference on Sustainable Development (ICSD). Bali 6 Maret 2012. 
Nisafani, A.S., Muqtadiroh, F.A., Muklason, A., 2012. Wisdom Management System Framework for Sustainable Heritage Conservation. In Seminar Sistem Informasi Indonesia (SESINDO). Surabaya, 22 Nopember 2012.

Nisafani, A.S., Muqtadiroh, F.A., Fitrianto, N., 2014. Analisis dan Perancangan WikiBudaya dalam Rangka Melestarikan Budaya Bangsa dan Kearifan Lokal Nusantara. SISFO-Jurnal Sistem Informasi, Vol. 5(No. 2).

budaya-indonesia.org., 2007. Perpustakaan Digital Budaya Indonesia. Dapat diakses di http://budaya-indonesia.org/ [Diakses pada 10 Desember 2014]

DPD, D. P. D. R. I., 2012. Program Perlindungan Kekayaan Budaya Kementerian Pendidikan Dan Kebudayaan. Dapat diakses di http://www.dpd.go.id [Diakses pada 15 Desember 2014]
Erikkson, Joakim; Ek, Asa; Johansson, G., 2000. Design and evaluation of a software prototype for participatory planning of environmental adaptations. Ieee Transactions on Rehabilitation Engineering, Vol. 8(No. 1), 94-106.

Muqtadiroh, F.A., Nisafani, A.S., Misbach, M., 2014. Pembangunan Perangkat Lunak Wikibudaya dalam Rangka Melestarikan Budaya Bangsa dan Kearifan Lokal Indonesia. In Seminar Sistem Informasi Indonesia. Surabaya, 22 September 2014.

Purwaningsih, E., 2012. Partisipasi Masyarakat dalam Perlindungan Hukum terhadap Kekayaan Intelektual Warisan Bangsa. In Naskah buku teks DIKTI.

Wikipedia, 2001. Halaman Utama Wikipedia. Diambil dari http://id.wikipedia.org/wiki/Halaman_Utama [Diakses pada 10 Desember 2014] 